\title{
Structural evaluation and animal implantation of porous eggshell waste- derived hydroxyapatite graft as bone substitution
}

\author{
Yudha Mathan Sakti ${ }^{*}$, Rahadyan Magetsari ${ }^{1}$ \\ 1 Departement of Orthopaedi and Traumatologi Dr. Sardjito General Hospital, \\ Faculty of Medicine Universitas Gadjah Mada, Yogyakarta, Indonesia
}

\begin{abstract}
The development of hydroxyapatite graft with high economically value is needed for orthopedic practice in developing countries. Eggsell waste is well known as natural substance for calcium resource. It has been used as raw material in producing hydroxyapatite. This study was conducted to synthesize porous hydroxyapatite from eggshell waste and evaluate its activity as bone substitution. The porous hydroxyapatite graft was manufactured from eggshell and sugar as a raw material using hydrothermal process. The porous eggshell waste-derived hydroxyapatite (EW-HAP) graft was characterized using $X$ ray difractometer (XRD) and analytical scanning electron microscope (SEM) and compared with commercial hydroxyapatite (HAP) JCPDS 09-432 graft (Bangros ${ }^{\oplus}$ ) as standard. The porous EW-HAP graft obtained was then implanted on critically sized femoral defects surgically created in the right thigh of male Wistar rats (Rattus norvegicus) with Bangros ${ }^{\circ}$ as control. Radiological examination using XRD and histological examination using hematoxyline-and-eosin staining of the bone femour were performed at 28 days after implantation. The results showed that the XRD pattern for EW-HAP was likely similar with the HAP standard. However, the SEM examination showed that the pasticle size of EW-HAP graft (2.5-3 $\mu \mathrm{m})$ was higher than those HAP standard graft $(1.5-2 \mu \mathrm{m})$. Radiographs according to the International of Limb Salvage (ISOLS) radiological evaluation system between EW-HAP graft $(6.1 \pm 1.45)$ and HAP control graft $(6.9 \pm 2.10)$ was not significantly different $(p>0.05)$. Moreover, histological examination according to Lane and Shandu scoring system between the both graft $(4.0 \pm 0.94$ versus $4.4 \pm 0.92)$ was also not significantly different $(p>0.05)$. It can be concluded that the structure EW-HAP graft is similar with HAP graft standard. The both grafts have also equal outcome as bone substitution.
\end{abstract}

\section{ABSTRAK}

Pengembangan graft hidroksiapatit dengan nilai ekonomi tinggi diperlukan dalam bidang ortopedi di negara berkembang. Limbah cangkang terus dikenal luas sebagai bahan alam sumber kalsium. Limbah cangkang telur telah digunakan sebagai bahan untuk menghasilkan hidroksiapatit. Penelitian ini dilakukan untuk mensintesis graft hidroksiapatit berpori dari limbah cangkang telur dan mengkaji aktivitasnya sebagai pengganti tulang. Graft hidroksiapatit berpori dibuat dari bahan dasar cangkang telur (HAP-LCT) dan gula menggunakan proses hidrotermal. Graft yang dihasilkan dikarakterisasi difraktometer X-ray (DXR) dan mikroskop elektron skaning (MES) analitik dan dibandingkan dengan graft JCPDS 09-432 hidroksiapatit komersial (Bangros ${ }^{\circ}$ ) sebagai standar. Graft berpori HAP-LCT yang diperoleh kemudian diimplantasikan pada critically sized tulang femur yang dibuat melalui operasi pada paha kanan tikus Wistar jantan (Rattus norvegicus) dengan Bangros ${ }^{\circ}$ sebagai kontrol. Pemeriksaan radiologi menggunakan DXR dan histologi dengan pengecatan hematosilin-eosin tulang femur dilakukan pada hari ke 28 setelah implantasi. Hasil

\footnotetext{
* corresponding author: mathan_sakti@yahoo.com
} 
penelitian menunjukkan bahwa gambaran DXR graft HAP-LCT sama dengan graft HAP standar. Namun demikian, hasil pemeriksaan MES menunjukkan ukuran partikel HAP-LCT $(2,5-3 \mu \mathrm{m})$ lebih tinggi dari pada graft HAP standar $(1,5-2 \mu \mathrm{m})$. Gambaran radiografi menurut sistem evaluasi radiologi International of Limb Salvage (ISOLS) graft HAP-LCT $(6,1 \pm 1,45)$ dan and graft HAP kontrol $(6,9 \pm 2,10)$ berbeda bermakna $(p>0.05)$. Lebih lanjut dari hasil pemeriksaan histologi menurut sistem penilaian Lane dan Shandu antara kedua graft $(4,0 \pm 0,94)$ tidak berbeda bermakna $(p>0,05)$. Dapat disimpulkan bahwa struktur graft HAP-LCT sama dengan graft HAP standar. Kedua graft juga mempunyai luaran sama sebagi pengganti tulang.

Key words: eggshell - porous hydroxyapatite graft - bone substitution - X-ray

\section{INTRODUCTION}

In orthopedic and traumotology, bone damage or bone defect is one of health problems that can cause mechanical instability, dead space for bacterial infection and hampered bone healing process. ${ }^{1}$ Extensive bone damage can not heal spontaneously, therefore a bone graft procedure is needed. ${ }^{2}$ In USA, at least 2.2 million bone grafting have been conducted annually with 300 million US \$ are spent over one year period. ${ }^{3,4}$ The bone graft is expected to increase mechanical stability of bone and bone healing process. ${ }^{5}$

Bone grafting having biomaterial properties that obtained from patient's own tissue (outologous bone graft) is considered to to be the most ideal of bone graft. However, the outologous bone graft has several limitations such as donor morbidity, tissue rejection and disease transmission. ${ }^{5-6}$ Recently, synthetic materials have been developed as synthetic bone graft to solve the problem. One of them is carbonated hydroxyapatite which has crystallographic similarity with human bone, excellent osteoconductivity and good resorption rate. ${ }^{7,8}$

Eggsell waste has been used as natural substance for calcium resource. The major cosntituent present in the eggshell is $\mathrm{CaCO}_{3}$, which account around $91 \%$ of the total weight. Eggshell waste is available in huge quantity from food processing, egg breaking and hatching industries. ${ }^{9}{ }^{10}$ It has been used as raw material in producing hydroxyapatite and used as attractive biomedical materials. In this study a porous eggshell waste-derivet hydroxyapatite (EW-HAP) graft has been synthesized and its application as bone substitution on critically sized femoral defect in animal rats has been performed.

\section{MATERIALS AND METHODS}

\section{Fabrication of porous EW-HAP graft}

The hydroxyapatite graft was made from eggshell waste as a raw material. The eggshell was washed, dried and then powdered using mechanical bowl mill in order to obtain a soft powder. The powder was sifted using a sieve with diameter of 270 mesh to obtain powder with a particle size of $53 \mu \mathrm{m}$. Calcination process of the powder was conducted by heating with holding time at $900{ }^{\circ} \mathrm{C}$ for four hours in order to change $\mathrm{CaCO}$ s to $\mathrm{CaO}$. Hydroxyapatite was synthesized from $\mathrm{CaO}$ as a raw material using hydrothermal process. The $\mathrm{CaO}$ powder was mixed with $0.5 \mathrm{M}$ diammonium hydrogen phosphate and heated at $400{ }^{\circ} \mathrm{C}$ until eggshell waste-derivet hydroxyapatite (EW-HAP) powder obtained. Porous eggshell waste-derivet hydroxyapatite graft was made by mixing of EWHAP powder and sugar (1:1). The mixture was then mechanically compacted using isostatic presurizing (CARVER Hydraulic model 3912) at a pressure of $10 \mathrm{Mpa}$. The porous EW-HAP graft was obtained after sintering process at 
$1300{ }^{\circ} \mathrm{C}$ for two hours performed. The porous EW-HAP graft was characterized using $\mathrm{X}$ ray difractometer (XRD Rigaku) to examine its chrystallography phase and purity and compared with an hydroxyapatite crystal standard of JCPDS (09-432) $\left[\mathrm{Ca}_{5}\left(\mathrm{PO}_{4}\right)_{2}(\mathrm{OH})\right]$. Further- more, the structure and morphology of EW-HAP graft was analized using Analytical Scanning Electron Microscope/SEM (JEOL type JSM636OLA). The fabrication process flow chart of the porous EW-HAP graft is presented in FIGURE 1.

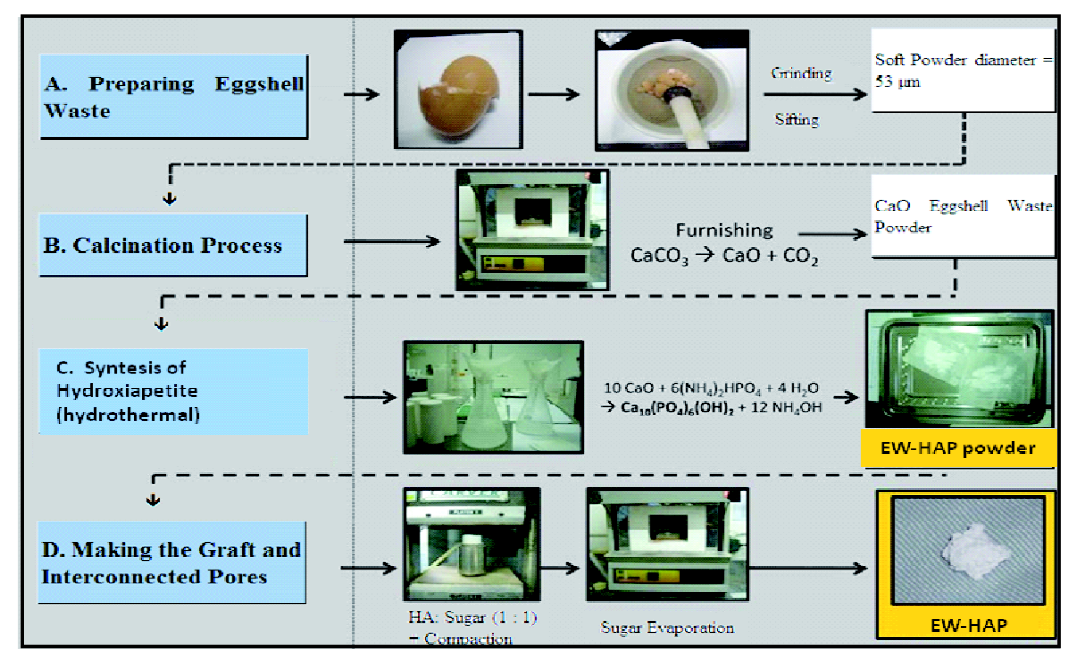

FIGURE 1. The fabrication process flow chart of the porous EW-HAP graft

\section{Implantation of the porous EW-HAP graft in critically sized femoral defect of animal}

Twenty healthy male Wistar rats (Rattus norvegicus) aged 12 to 16 weeks with 250 to 300 g body weight were used in the study. Critically sized femoral defects were surgically created in the right thigh of all rats. At the time of surgery, rats were randomly assigned to a treatment group $(\mathrm{n}=10)$, in which the femoral defect was filled with EW-HAP graft and control group $(n=10)$, in which the femoral defect was filled with commercial HAP graft JCPDS 09-432 (Bongros ${ }^{\circledR}$ ). Clinical and physical examination was performed during 28 days experimental. Rats were sacrificed at 28 days after implantation.

Anterior-posterior and lateral radiological examination using X-ray diffractometer (XRD) of bone femour of the right thigh were performed at 28 days after implantation. Radiographs were obtained and evaluated for bone union and bone resorption according to the International Society of Limb Salvage (ISOLS) radiological implants evaluation system after modification.

The operated bone femur sample was decalcified in formic acid working solution for seven days. Sample was then embedded in paraffin and cut longitudinally into $5 \mu \mathrm{m}$ thick sections. Sections were stained with hematoxyline-and-eosin (H\&E). Histological examination was performed according to Lane and Shandu scoring system as modified by Heiple et al. ${ }^{11}$

Radiological and histological data were expressed as mean \pm standard deviation. A statistical analysis of data was performed using Mann Whitney U Test. Probability values (p) for significance were calculated, with $p<0.05$ considered significant. The animal application flow chart of the porous EW-HAP graft and 
commercial HAP graft is presented in FIGURE 2. All precedures have been approved by the Health Research Ethics Committee of the Faculty of Medicine, Universitas Gadjah Mada, Yogyakarta.

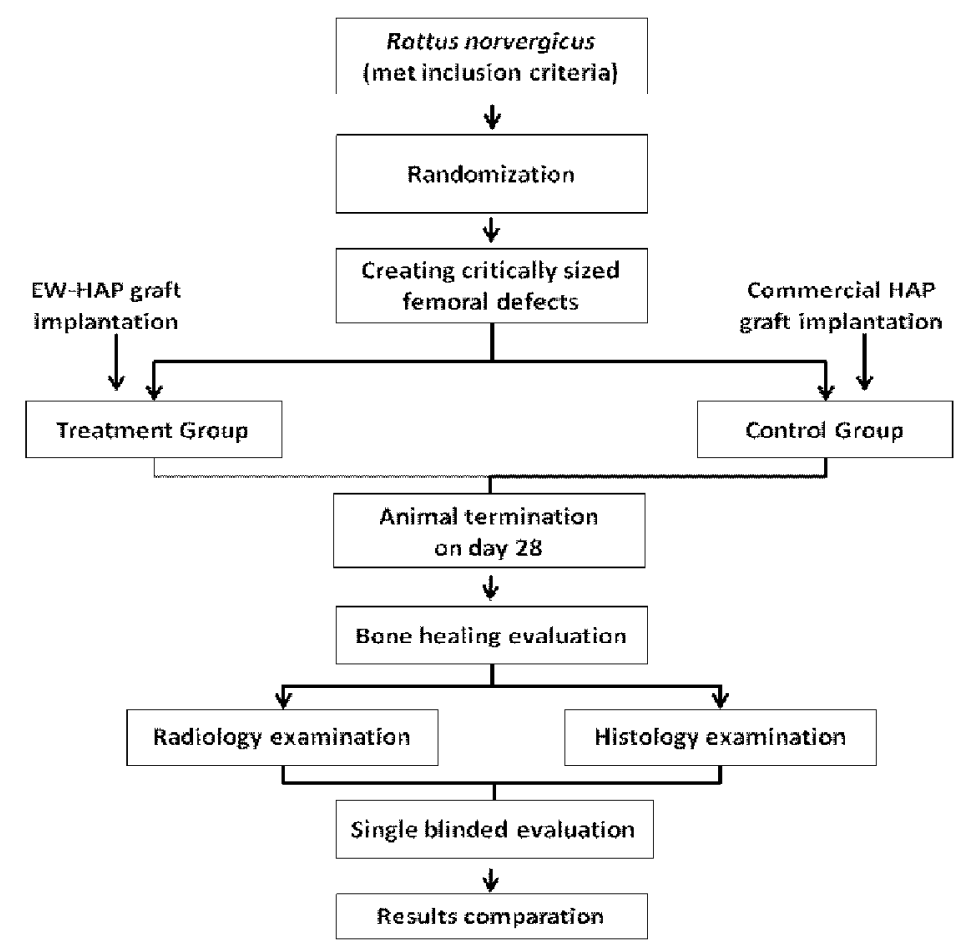

FIGURE 2. The animal application flow chart of the porous EW-HAP graft

\section{RESULTS}

\section{Fabrication of porous eggshell waste- derivet hydroxyapatite (EW-HAP) graft}

FIGURE 3 illustrates the X-ray diffraction pattern for EW-HAP(A), JCPDS (09-432) HAP control/Bongros $^{\circledR}(\mathrm{B})$; human HAP $(\mathrm{C})$ and bovine HAP (D). The X-ray diffaction pattern for EW-HAP was likely similar with the HAP standard, human HAP as well as bovine HAP.
The XRD examination was performed with max rated output of $2 \mathrm{~kW}$, rated voltage from 20 to $50 \mathrm{kV}$, rate current from 2 to $50 \mathrm{~mA}$ and $\mathrm{Cu}$ target $(\mathrm{K} \pm=1,54060 \AA)$. The intensity data were collected in $0.02^{\circ}$ steps in the 2 , range, from 0 to $90^{\circ}$. The EW-HAP had 17 peaks with major peaks observed between 30 and $40^{\circ}$. The EWHAP highest peak was observed at $32.14^{\circ}$ in the 2 , with intensity of 90 Io. 

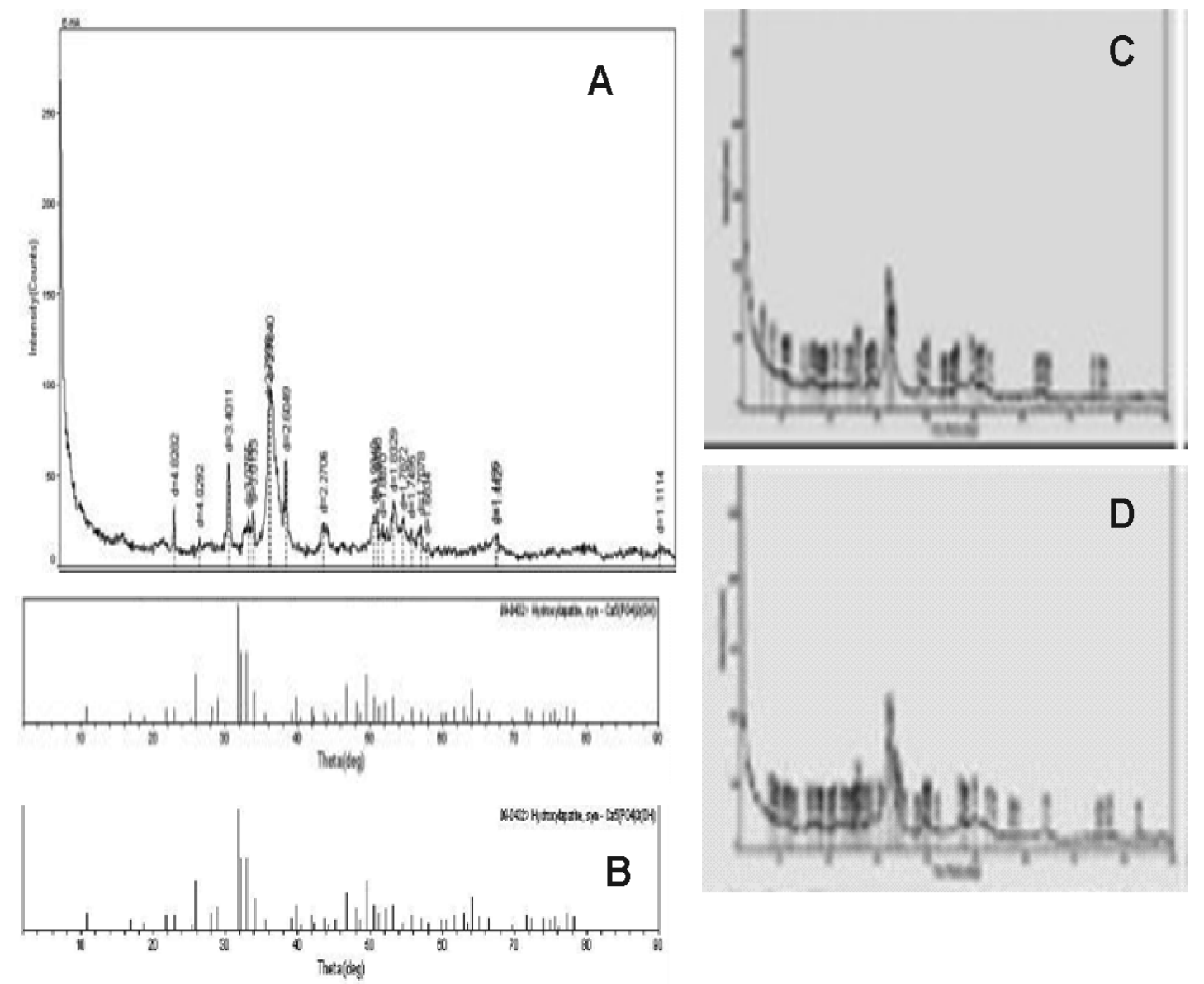

FIGURE 3. X-R Diffraction pattern of EW-HAP (A); HAP control/Bongros ${ }^{\circledR}$ (B) human HAP (C) and bovine HAP (D)

The SEM examination result of EW-HAP comparet with HAP control are presented in FIGURE 4. In magnitude of 50 times, the morphology of EW-HAP surface was likely more rough, irregular, random with irregular pore size of $150-500 \mu \mathrm{m}$. Whereas the HAP control $\left(\right.$ Bangros $\left.^{\circledR}\right)$ suface appeared more fine with regular pore size of $300-500 \mu \mathrm{m}$. In magnitude of 2500 times, both of HAP appeared a regular crystal form with particles in were in micron dimension. The microstructure consisted of microsized agglomerates HAP and they were tightly bonded to each other. However, the difference in particles size of both HAP clearly observed in the magnitude of 2500 times. The pasticle size of EW-HAP $(2.5-3 \mu \mathrm{m})$ was higher than those HAP control (1.5-2 $\mu \mathrm{m})$. 

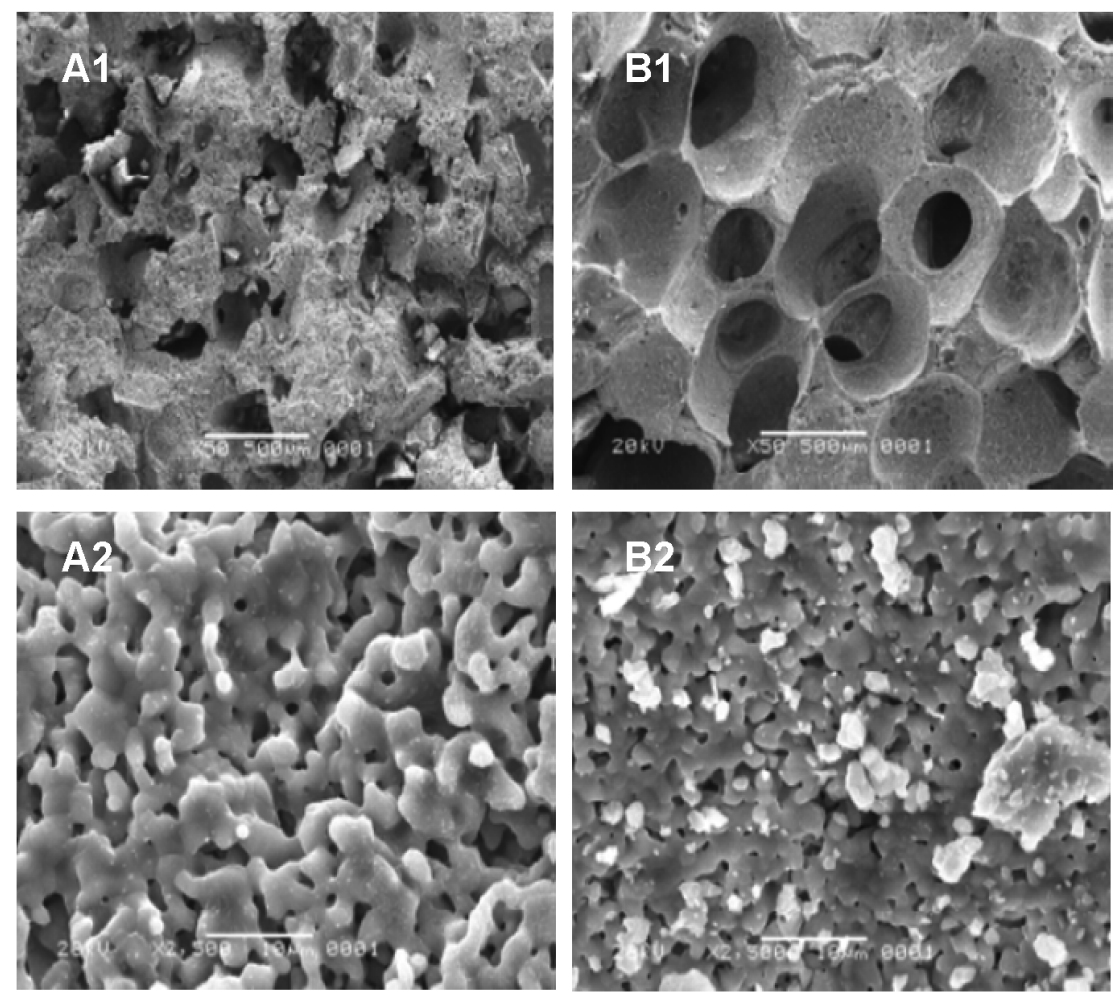

FIGURE 4. The SEM examination results of EW-HAP in magnitude $50 \times(\mathrm{A} 1)$, magnitude $2500 \times(\mathrm{A} 2)$, HAP control magnitude $50 \times$ (B1) and magnitude $2500 \times(\mathrm{B} 2)$

\section{Implantation of the porous EW-HAP graft in critically sized femoral defect of animal}

The physical and clinical conditions of rats after implantation of the porous EW-HAP graft or HAP control graft during 28 days observation are presented in TABLE 1 . During 28 days observation periode, two rats on the HAP control group were excluded due to wound infection. In general the others rats exhibited good physical and clinical conditions. On day 14, hemispica removal and operation wound care were conducted. Fixation of hemispica on four rats i.e. two in each group was torn. Post operative swelling was observed on five rats i.e. two in EW-HAP graft group and three in HAP control group. Tissue necrosis on distal hemispica was observed only in one rat of HAP control group. 
TABLE 1. Physical and clinical conditions of rats on EW-HAP treatment graft group and HAP control graft group during 28 days observation

\begin{tabular}{|c|c|c|c|c|c|c|}
\hline \multirow{2}{*}{ Groups } & \multirow{2}{*}{ General } & \multicolumn{4}{|c|}{ Local status } & \multirow{2}{*}{ Notes } \\
\hline & & Hemispica & Swelling & Infect & Necros is & \\
\hline \multicolumn{7}{|c|}{$\begin{array}{l}\text { HAP control } \\
{\left(\text { Bongros }^{(\mathbb{B})}\right)}\end{array}$} \\
\hline - 1 & Active & + & - & + & - & $\mathrm{DO}$ \\
\hline - 2 & Active & + & - & - & - & \\
\hline - 3 & Active & Torn & - & - & - & \\
\hline - 4 & Active & Torn & + & - & - & \\
\hline .5 & Active & + & - & - & - & \\
\hline - 6 & Active & + & - & - & - & \\
\hline$\cdot 7$ & Aclive & + & - & - & - & \\
\hline$\cdot 8$ & Active & + & + & + & + & $\mathrm{DO}$ \\
\hline - 9 & Active & । & - & - & - & \\
\hline$\cdot 10$ & Active & + & - & - & - & \\
\hline \multicolumn{7}{|c|}{ EW-HAP } \\
\hline - 1 & Active & + & - & - & - & \\
\hline - 2 & Active & + & - & - & - & \\
\hline - 3 & Active & + & - & - & - & \\
\hline - 4 & Active & + & - & - & - & \\
\hline$\cdot 5$ & Active & + & - & - & - & \\
\hline .6 & Active & Torn & - & - & - & \\
\hline$\cdot 7$ & Active & + & + & - & - & \\
\hline - 8 & Aclive & ToIn & - & - & - & \\
\hline - 9 & Active & + & + & - & - & \\
\hline - 10 & Active & + & + & - & - & \\
\hline
\end{tabular}

Note : $\mathrm{DO}=$ drop out

Representative of X-Ray of bone femour on 28 days after implantation of EW-HAP graft and HAP graft control are presented in TABLE. Whereas, the representative of histological section of bone femour on 28 days after implantation EW-HAP graft is presented in TABLE 6. 

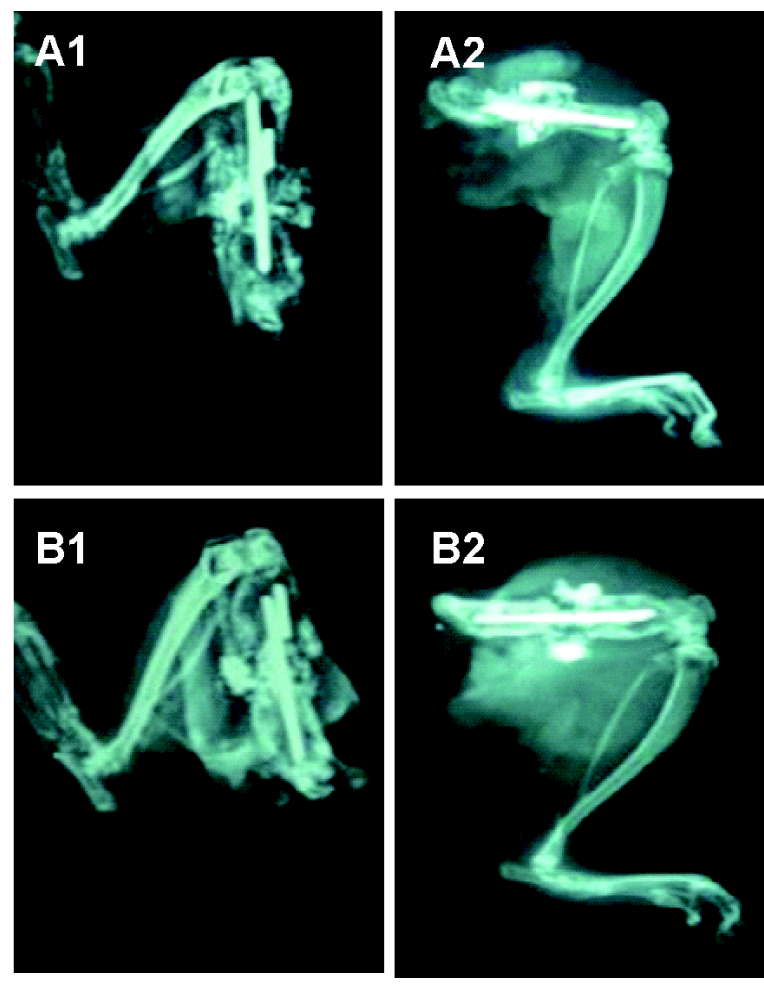

FIGURE 5. Representative of X-Ray of bone femour on 28 days after implantation. A1 (anterio-posteriol) and A2 (lateral) views of EW-HAP graft. B1 (anterio-posteriol) and B2 (lateral) views of HAP graft control
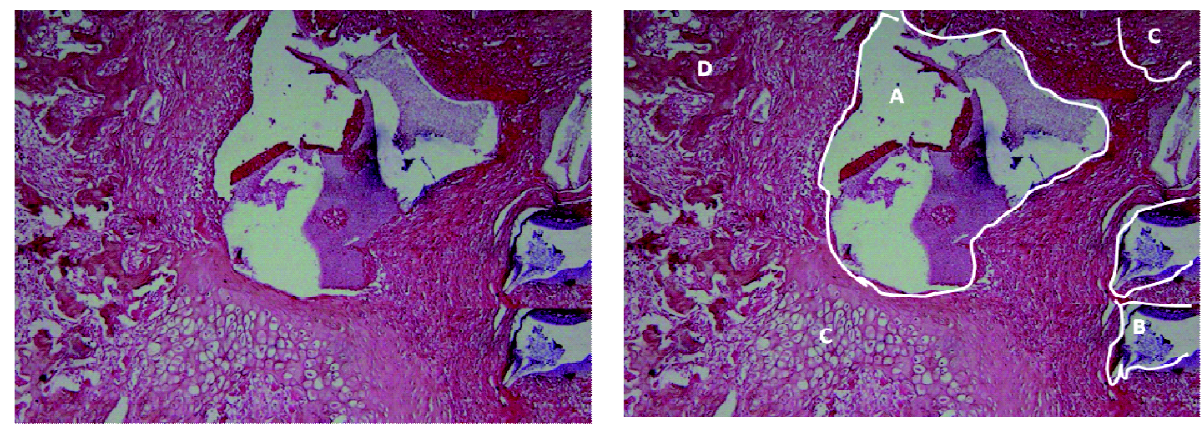

FIGURE 6. Representative histological section of bone femour on 28 days after implantation EW-HAP graft. A and B (EW-HAP graft), C (osteochondral tissue), D (osteoid and new bone cells).

The results of radiological and histological examination of of bone femour of the right thigh of rats of both groups are presented in TABLE 2. No signifantly difference in radiological and histological pictures were observed after EWHAP graft compare to HAP graft control implantation on 28 days $(\mathrm{p}>0.05)$. 
TABLE 2. Radiological and histological examination of of bone femour of the right thigh of rats on EW-HAP graft and HAP control graft groups

\begin{tabular}{|c|c|c|c|c|c|c|c|c|}
\hline \multirow{2}{*}{ Examination } & \multirow{2}{*}{ Il } & \multicolumn{3}{|c|}{ EW -HAP gra $\mathrm{ft}$} & \multicolumn{3}{|c|}{ HAP control graft } & \multirow{2}{*}{$p^{*}$} \\
\hline & & Min & Max. & Mean $\pm \mathrm{SD}$ & Min. & Max. & Mean \pm SD & \\
\hline XRD & 8 & 4 & 8 & $6.1 \pm 1.45$ & 3 & 55 & $6.9 \pm 2.10$ & 0.364 \\
\hline Histology & 10 & 3 & 6 & $4.0 \pm 0.94$ & 3 & 35 & $4.4 \pm 0.92$ & 0.338 \\
\hline
\end{tabular}

Note: Min= minimum; Max=maximum; *Mann Whitney $U$ Test with $p<0.05$

\section{DISCUSSION}

The synthesis HAP graft from eggshell as raw material of calcium source has been conducted by some authors. ${ }^{9,12,13}$ Eggshell waste is available in huge quantity from food processing, egg breaking and hatching industries. About 250,000 tons of eggshell waste is produced annually worldwide by food processing industry only. The process involved a simple hydrothermal reaction of calcium oxide obtained from the burning of eggshell. The hydroxyapatite crystal was formed through a chemical reactions as follows:

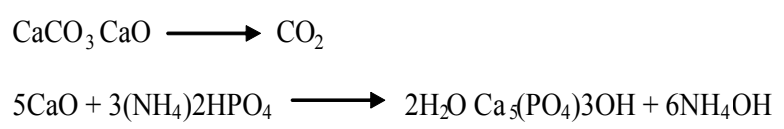

The XRD pattern for EW-HAP was likely similar with the HAP standard, human HAP as well as bovine HAP. The EW-HAP has similar peaks with HAP standard (JCPDS 09-432). The highest peak of HAP standard was observed at $31.73^{\circ}$ in the 2 , with intensity of $100 \mathrm{Io}$, while the highest peak of EW-HAP was observed at $32.14^{\circ}$ in the 2 , with intensity of 90 Io. The similarity of the both graft was also indicated with major peaks observed between 30 and 40 ${ }^{\circ} \mathrm{C}$. In addition, EW-HAP was likely similar with the human dan bovine HAP that produced by Herliansyah. ${ }^{14}$

The morphoplogy of EW-HAP surface was likely more rough, irregular and random in the SEM examination. In this study sugar was used to obtain a porous EW-HAP graft. Symsudin reported that the use of sugar as porogen provided HAP graft with rough, irregular and random surface. ${ }^{15}$ Morphologically, it seems a sugar crystale which have cube-shaped or irregular square in the form of three-dimensional mixed. ${ }^{16}$ However, the SEM examination showed the EW-HAP graft had similarity with previous studies. ${ }^{15,17-19}$ The EW-HAP had ideal porous diamter to help for better osteogenic cells attachment and bone healing process.

In general, all rats exhibited good physical and clinical conditions after implantation of the porous EW-HAP or HAP control grafts during 28 days observation. The results of radiological and histological examination of bone femour of the right thigh of rats after EW-HAP graft implantation were not significantly compare to those HAP graft control. It was indicated that EW-HAP exhibited similar outcome as bone substituion compare to HAP control graft $\left(\right.$ Bangros $^{\circledR}$ ).

Studies the use of EW-HAP as bone graft substitution have been reported by some authors. Park et al. ${ }^{20}$ evaluated of bone healing with hen eggshell-derived bone graft substitutes in rat calvaria and showed the potential efficacy of hen eggshell-derived bone graft as an osteoconductive bone substitute in a rat calvarial defect model. Lee et al. ${ }^{21}$ compared hydroxuapatite from eggshell and synthetic hydroxyapatite for bone regeneration and reported that both eggshell and synthetic 
hydroxyapatite showed highe bone formation than unfilled control. However, eggshell hydroxyapatite had significantly higher bone formation then the unfilled control at eight weels after operation. Durmus et al..$^{22}$ evaluated the biocompatibility and osteoproductive activity of ostrich eggshell powder in experimentally induced calvarial defect in rabits. The result showed that ostrich eggshell powder was a worth-while bone substitute because it is a safe, cheap, and easily available material.

\section{AKNOWLEDGEMENTS}

We would like to thank all technicians who gived valuable assistence druring the study.

\section{CONCLUSION}

The synthesis of hydroxyapatite from eggshell waste and sugar as raw materials has been successed performed providing porous EW-HAP graft. The structure and morphology of EW-HAP graft iss likely similar with the HAP standard (Bangros ${ }^{\circledR}$ ). Furthermore, the implantation of EW-HAP graft of bone femour of the right thigh of rats provide similar outcome outcome as bone substituion compare to HAP control graft $\left(\right.$ Bangros $\left.^{\circledR}\right)$.

\section{REFFERENCES}

1. World Health Organization. Global burden of disease: global programme on evidence for health policy discussion paper 50. Geneva : World Health Organization, 2000.

2. Phelps JB, Hubbard GB, Wang X, Agrawal CM. Microstructural heterogeneity and the fracture toughness of bone. J Biomed Mat Res 2000; 51:735-41.

3. Lewandrowski KU, Gresser JD, Wise DL, Trantol DJ. Bioresorbable bone graft substitutes of different osteoconductivities: a histologic evaluation of osteointegration of poly(propylene glycol-co-fumaric acid)-based cement implants in rats. Biomaterials 2000; 21(8):757-64.
4. Thomas C, Burg KJL. Tissue engineered bone replacements systems. Eur Cells Mat 2007; 13(2): 1-2.

5. Camillo FX. Arthrodesis of the spine. In: Canale ST \& Beaty JH editors. Campbell's operative orthopaedics, $11^{\text {th }}$ eds. Philadelphia: Mosby Elsevier, 2007; 1851-2.

6. De Long WG, Einhorn TA, Koval K, McKee M, Smith W, Sanders, R et al. Bone graft and bone graft substitutes in orthopaedic trauma surgery: a critical analysis. J Bone Joint Surg Am 2007;89:649-58. Doi:10.2106/JBJS.F.00465.

7. Jamali A, Hilpert A, Debes J, Afshar P, Rahban S, Holmes R. Hydroxyapatit/calcium carbonate versus plester of Paris: a histomorphometric and radiographic study in a rabbit tibial defect model. Calcif Tissue Int 2002;71:172-78.

8. Orsini G, Ricci J, Scarano A, Pecora G, Petrone G, Iezzi G. Bone-defect healing with calciumsulfate particles and cement: an experimental study in rabbit. J Biomed Mater Res Part B 2004; 199-208.

9. Raihanan MF, Sopyan I, Hamdi M, Ramesh S. Novel chemical conversion of eggshell to dydroxyapatite powder. In: Osman NAA, Ibrahim F, Wan WABA, Rahman HSA, Ting HN editors. Proceedings of the 4th Kuala Lumpur International Conference of Biomedical Engineering; 2008 June 25-28, Kuala Lumpur, Malaysia.

10. Sasikumar S and Vijayaraghavan. Low temperature synthesis of nanocrystalline hydroxyapatite from eggshells by Combustion method. Trens Biomater Artif Organs 2006; 19(2):70-3.

11. Heiple KG, Goldberg VM, Powell AE, Bos GD, Zika JM. Biology of cancellous bone grafts. Orthop Clin N Am 1987;18: 179-85.

12. Saeed AM, Hassan RA, Thajeel. Synthesis of calcium hydroxyapatite powder from hen's eggshell. Iraqi J Phys 2011; 9(16): 24-8.

13. Kumar S. Eggshell derived nanophase bioceramics. Archives of BioCeramics Research Volume 9. Proceeding of the $9^{\text {th }}$ Asian Bioceramics Symposium; 2009 December 8-11, Nagoya, Japan.

14. Herliansyah MK. Development and fabrication of bovine hydroxyapatie bone graft for biomedical application [Ph.D thesis]. Kualalumpur: University of Malaya, Malaysia, 2009.

15. Syamsudin. Analisis uji tekan dan porositas material kompaksi sinter $\mathrm{HA} / \mathrm{ZnO}$ sebagai material 
substitusi tulang [Tesis S-2]. Yogyakarta: Bidang Rekayasa Biomedis, Universitas Gadjah Mada.

16. Hynes RC, Le Page Y. Sucrose, a convenient test crystal for absolute structures. J Appl Crystallograp 1991; 24 (4): 352. Doi:10.1107/ S0021889891002492.

17. Lee JH, Hwang CJ, Song BW, Koo KH, Chang BS, Lee CK. A prospective consecutive study of instrumented posterolateral lumbar fusion using synthetic hydroxyapatite (Bongros 1-HA) as a bone graft extender. J Biomed Mat Res 2009; 90A(3): 804-10. DOI: 10.1002/jbm.a.32113

18. Abdurrahim $\mathrm{T}$ and Sofyan I. Recent progress on the development of porous bioactive calcium phosphate for biomedical applications. Recent Patents on Biomedical Engineering 2008;1: 21329.

19. Damien E and Revell PA. Coralline hydroxyapatite bone graft substitute: a review of experimental studies and biomedical application. J Appl Biomat Biomech 2004; 2: 65-73.

20. Pa JW, Bae SR, Suh JY, Lee DH, Kim SH, Kim H, et al. Evaluation of bone healing with eggshellderived bone graft substitutes in rat calvaria: a pilot study. J Biomed Mater Res A 2008; 87(1):203-14.

21. Lee SW, Kim SG, Balázsi C, Chae WS, Lee HO. Comparative study of hydroxyapatite from eggshells and synthetic hydroxyapatite for bone regeneration. Oral Sur Oral Med Oral Phathol Oral Radiol 2012;113(3):348-55.

22. Durmus E, Celik I, Aydin AF, Yildirim G, Sur E. Evaluation of the biocompatibility and osteoproductive activity of ostrich eggshell powder in experimentally induced calvarial defects in rabbits. J Biomed Mat Res Part B Appl Biomat 2008; 86(1):82-9. 